11. Avatkov, V. A. Kochkin, M. V. (2016). Osobennosti otnoshenij Rossii so stranami Blizhnego i Srednego Vostoka na sovremennom jetape. Mezhdunarodnye otnoshenija, № 4, 327-336 (In Russian).

Матеріал надійшов до редакиї 11.12.2020 p.

УДК 327.8

Свген Суліма,

доктор філософських наук, професор, член-кореспондент НАПН України, директор ННІ гуманітарних наук,

Університет державної фіскальної служби України,

ORCID ID 0000-0002-8393-4591

35.01@nusta.edu.ua

DOI 10.29038/2524-2679-2021-01-33-45

\title{
ТРАНСФОРМАЦИЙНІ ПРОЦЕСИ У СВІТІ ТА ЇХ ВПЛИВ НА ФОРМУВАННЯ НОВОГО СВІТОВОГО ПОРЯДКУ
}

У статті розглянуто питання розподілу світу між розвиненими державами: чому виникає потреба розмежування країн за певною ознакою, яким чином проводиться розподіл, які структурні елементи беруть участь та що відбувається з геополітичною ситуачією внаслідок поділу сфер впливу. Наголошено на довготривалості, послідовності та невідворотності цих процесів. Наукова новизна статті полягає в тому, що автор не лише використовує філософію для побудови логічної моделі світового порядку, але й удається до використання історичного, економічного й політичного підходів для різнобічного аналізу иьього питання та позбавлення суб'єктивізму під час його оцінки. У дослідженні розглянуто поняття бі-, одно- та багатополярності, їх значення, суть, практичні приклади з історії людства. Проведено онтологічний аналіз світового порядку як важливої складової частини людського буття. Основну увагу приділено наддержавам США й СРСР. 3'ясовано, які чинники призвели до гегемонії цих крайн та які виклики ие створює для сьогодення. Важливу увагу приділено розпаду Радянського Союзу як природного завершення ичклу панування наддержави й падіння біполярної картини світу. У результаті зароджується новий світовий порядок із багатьма державами та міжнародними угрупуваннями на чолі, щзо свідчить про перехід до багатополюсного поділу світу за сферами виливу.

(C) Суліма $6 ., 2021$ 
Досліджено трансформаційні проиеси, які відбулися внаслідок иьього переходу, описано основних лідерів і претендентів на місце нового гегемона. Головним фаворитом є Китай: ретельно досліджено міжнародну діяльність, соиіальноекономічні показники, політику й власні думки Піднебесної стосовно позичії наддержави. Утім, у статті виділено изілу групу чинників наддержавності, яким об'єктивно не відповідають ні Китай, ні основні конкуренти, ЄС та Росія. Проаналізовано основні моменти, які гальмують вищезгадані країни та не дають їм змоги посісти місие нового світового гегемона.

Ключові слова: біполярність, однополярність, полічентричність, світовий порядок, новий світовий порядок, наддержава.

\section{1. ВСТУП}

Постановка проблеми. Після руйнування біполярної структури світу серед експертів і політиків розгорнулася дискусія про новий світовий порядок. Сперечалися переважно про те, буде він «однополюсним», «багатополюсним» (поліцентричним) або ж у новому якомусь складі відродиться біполярність. На жаль, дискусія була поспішною й поверховою. Тим часом актуальність і багатоаспектність цього питання вимагає його фундаментального аналізу за участі політологів, філософів, істориків, політекономів, соціологів і навіть демографів, щоб уникнути поверхових суджень у межах аналізу одних лише поточних міжнародних відносин або суб' єктивних зовнішньополітичних концепцій.

Аналіз останніх досліджень і публікацій. Виділяють три основних підходи до тлумачення та аналізу світового порядку: реалістичний (Г. Моргентау, А. Арон, К. Уолтц), структурно-конструктивістський (Х. Булл, Л. Міллер, Р. Купер, Р. Гілпін, Дж. Айкенбері), інституціональний (Я. Челтенхем, П. Катценштей, Р. Кохен, С. Краснер), аксіологічний (А. Етционі, Р. Летхем, Р. Фолк, С. Кім), біхевіористський (Дж. Розенау). Погоджуємося 3 позицією М. Наїма [1], який розглядає питання нового світового порядку як процесу організації співіснування країн світу та інших міжнародних акторів, що характеризується принципами, нормами, правилами й інструментами регулювання, визнаними всіма або більшістю країн світу та інших міжнародних акторів.

Мета статті - дослідити трансформаційні процеси, які відбулися внаслідок розпаду біполярної структури світу й переходу до багатополюсного поділу світу за сферами впливу.

Методичні основи дослідження. Мета дослідження - комплексний аналіз із використанням порівняння, абстрагування та конкретизації, 
виявлення причинно-наслідкових зв’язків і використання теоретичноаналітичних дослідницьких методів.

\section{2. РЕЗУЛЬТАТИ ДОСЛІДЖЕННЯ}

Структура біполярного світу виникла не в один день, а складалася протягом цілого історичного етапу; іiі кінець також став підсумком тривалого діалектичного процесу розвитку суперечностей, характерних для цієї моделі світопорядку. Новий світовий порядок також не виникає безпосередньо 3 розпадом старого: йому передує тривалий (щонайменше кілька десятиліть) перехідний період, протягом якого він формуватиметься на основі наявних компонентів, «будівельних матеріалів», що залишилися людству від минулого періоду історії.

Чи можливий однополярний світовий порядок? Деякі експерти (чиновники) i вчені вважають, що він уже сформований i потребує лише деякого «шліфування». Вони керуються простою арифметичною методикою: у період біполярності існували дві наддержави; зникнення однієї з них означало перехід до однополюсності. Тим часом ми можемо поки що з упевненістю констатувати лише факт збереження однієї з компонент біполярності, яка зі зникненням противаги втратила об'єктивну основу існування. В епоху біполярності США й СРСР дійсно були наддержавами. Головна відмінність наддержави від великої держави полягає в тому, що в умовах протистояння «двох таборів», великих груп держав, кожна 3 наддержав відіграє роль лідера та гегемона, що веде за собою свою групу й несе основну відповідальність за іiі безпеку. Саме визнання (більш-менш добровільне) за будь-якою державою наддержавного лідерства зумовлене якраз небезпекою, що надходить від групи на чолі 3 іншою наддержавою. Через це зі зникненням ситуації біполярної ідеологічної (i пов’язаної 3 нею військово-політичної) конфронтації зникає й основа для наддержавної функції. Так, починаючи з 1990-х років, перед США постало воістину історичне завдання - трансформуватися з наддержави в просто велику державу, нехай навіть першу, але на рівноправній основі. Більше того, ураховуючи, що до цього часу в США вперше у світі виник і почав швидко розвиватися постіндустріальний інформаційно-технологічний устрій, США могли б, і не вдаючись до традиційних (але улюблених) військово-політичних механізмів, зійти на п'єдестал єдиного світового лідера.

Найбільш проникливі представники американської інтелектуальної еліти, стурбовані картиною явного занепаду привабливості та впливу 
США за кордоном, скороченням питомої їх ваги у світовому валовому продукті, величезною заборгованістю (найбільшою у світі), численними $\mathrm{i}$, зазвичай, невдалими збройними втручаннями у справи зарубіжних країн (здебільшого без санкцій Ради Безпеки ООН), які не додавали престижу США, неодноразово виступализ рецептамизміцненняїх світовоголідерства. Серед них значне місце займає відомий політолог, професор Гарвардського університету Джозеф Най, автор зовнішньополітичної концепції «м’якої сили». У зв’ язку з публікацією своєї книги «Чи настав кінець Американського століття?» («Is the American Century Over?») Най дав коротке інтерв’ю журналу «Тіте», у якому на це запитання впевнено відповів: «Не так скоро» («Not so fast») [2]. Най вірить у перевагу американської геополітики, загрозу якій становлять не Китай, Індія або Росія, а сама Америка. Із військового погляду, у США все в порядку - це «глобальний бегемот», який витрачає на озброєння в чотири рази більше, ніж Китай, що перебуває на другому місці за цим показником у світі. Більше того, військовий бюджет США перевищує сукупні витрати наступних за ними в рейтингу восьми країн [3]. За ВВП Китай уже практично перевершив США; проте, відзначає Най, близько половини з 500 найбільших міжнародних корпорацій належать американським громадянам, а $з$ топ-25 світових брендів 19 -американські. Ключовим же, на його думку, є те, що США продовжать займати панівне становище у світі завдяки відсутності «життєздатного противника»: СС «занадто фрагментарний», Японія «стара», Росія «корумпована», Індія «бідна», а Бразилія «малопродуктивна». Вплив Китаю на світовій арені зростатиме, але й він стикається із серйозними внутрішніми викликами, які можуть стати причиною «сходження з рейок». Так, КНР не вистачає «інгредієнта», який робить Америку унікальною країною, - відкритості для імміграції. Перспектива втрати США цієї своєї унікальної риси та переходу до ізоляціонізму дуже турбує Ная. Якщо політичний ізоляціонізм стане постійною рисою американської зовнішньої політики й зростання майнової нерівності продовжиться, це створить загрозу домінуванню Америки у світі. Звичайно, додає він, США не безгрішні. Так, великими помилками стали вторгнення в Ірак і непохитна позиція з проблеми зміни клімату. Але важко уявити собі, що світ стане кращим, якщо ним будуть правити В. Путін або Сі Цзіньпін, - підсумовує професор.

Тим часом незабаром після виходу інтерв'ю з Наєм його аналіз щодо Китаю піддався серйозному випробуванню. Відсутність у Китаю згаданого унікального американського чинника не завадила йому на регіональному Азійському терені завдати відчутного удару по Вашингтону, а заодно й по 
контрольованим ним певною мірою Світовому банку й Азійському банку розвитку. Коли у 2013 р. Китай оголосив про намір заснувати в Шанхаї Азіатський інфраструктурний інвестиційний банк (Asian Infrastructure Investment Bank), Вашингтон виступив проти та наполегливо рекомендував своїм союзникам як в Азії, так і в Свропі не підтримувати цю ініціативу. Тоді союзники послухалися. Але після того, як на початку 2015 р. вже 26 країн, переважно Азії й Близького Сходу приєдналися до проєкту АІІБ, першою в Свропі не втрималася Великобританія, висловивши бажання взяти участь у роботі банку. Негайною була ланцюгова реакція: до організації приєдналися Франція, Німеччина та Італія, а такі країни, що спочатку відмовилися, як-от Австралія та Південна Корея, почали переговори 3 Китаєм про умови участі. Відомий оглядач газети Financial Times Гідеон Рахман охарактеризував ці події таким чином: вступивши в протиборство й програвши Китаю, Вашингтон мимоволі дав світу сигнал про зміщення центру сили та впливу у XXI ст. [4].

Історичний досвід усіх великих імперій свідчить, що їхніх політичним елітам психологічно вкрай важко подолати «синдром наддержавності». Hi президент Буш, ні президент Обама, ні президент Трамп не проявили помітних ознак готовності дослухатися до тверезих і розумних порад низки експертів. Формується враження, що в результаті тривалого й безвідповідального вихваляння нібито неперевершеною міццю США всі адміністрації Сполучених Штатів і справді повірили, що політика сили $€$ панацеєю для розв'язання всіх дійсних та уявних проблем, які постають перед країною. Майже всі президенти США відкрито й самовіддано говорили у своїх численних виступах про практично месіанське призначення світового лідерства Америки.

Але $\epsilon$ в США й експерти, які час від часу опускають президентів своєї країни з їх месіанських висот на грішну землю. У кінці 2014 р. один із них, відомий політолог Джордж Фрідман, глава приватного аналітичного агентства «Stratfor», яке часто називають «тіньовим ЦРУ», дав інтерв”ю газеті «Коммерсант» [5]. За його словами, справжня мотивація дій США на зовнішньополітичній арені полягає в тому, щоб не дати жодній іншій державі зосередити у своїх руках занадто багато влади. Для цього США не зупиняються навіть перед неприкритими діями втручання у внутрішні справи інших держав.

Чи існує багатополюсний світ? «Багатополюсний (поліцентричний) світопорядок» - це, безумовно, уже не концепція, а об'єктивна історична реальність, формування якої триває й триватиме протягом перехідного періоду. Передумови цього переходу виникли ще «під шатром» 
біполярності. Обидві наддержави прагнули залучити до своїх таборів країни, що звільнялися від колоніальної та напівколоніальної залежності. США діяли батогом і пряником. 3 одного боку, використовувався механізм офіційної допомоги розвитку, у результаті багаторічної дії якого більшість країн, що розвиваються, потрапили у фінансову залежність від Заходу (виплати за основним займом плюс відсотки стали набагато перевищувати знову отримані кошти). 3 іншого боку, Штати обплутали країни й регіони зі стратегічно важливими ресурсами корисних копалин своїми військовими базами, спробували втягнути «ключові» держави, що розвиваються, у військово-політичні організації під своєю егідою: MEDO - Middle - East Defense Organization; CENTO - Central Treaty Organization; SEATO - SouthEast Asia Treaty Organization; ASPAC - Asian and Pacific council тощо. На пріоритетних маршрутах доставки цінних ресурсів на Захід США виставили свої військово-морські сили (5-й флот у зоні Перської затоки, 7-й флот у Південно-Східній і Північно-Східній Азії).

Після Другої світової війни предметом особливої турботи Вашингтона було встановлення контролю над нафтовими ресурсами в країнах, що розвиваються. УСШАбулий власнінафтовіресурси,якими вониполенд-лізу забезпечували під час війни своїх союзників (особливо Великобританію). Але президент Рузвельт був стурбований проблемою енергетичної безпеки в майбутньому. Ще в 1943-1944 pp. він обговорював питання консервації власної нафти на випадок Третьої світової війни зі своїм міністром внутрішніх справ Гарольдом Ікесом. Рузвельт доручив йому переговорити 3 Великобританією про необхідність освоєння після війни ресурсів Близького Сходу, що викликало занепокоєння Черчілля. Щоб заспокоїти його, на зустрічі з послом Великобританії Рузвельт показав йому схему розділу Близького Сходу. «Персидська нафта - ваша, - сказав він послу. - Нафту Іраку і Кувейту ми поділимо. Що стосується нафти Саудівської Аравії, то вона наша» [6, с. 51]. По суті, Рузвельт й Ікес заклали основи формування системи домінування на світовому нафтовому ринку протягом понад чверті століття після закінчення світової війни англо-саксонської групи корпорацій, що отримала назву «семи сестер» (Exxon, Mobil, Chevron, Gulf, Texaco, BP, Royal Dutch/Shell). У подальшому «сестри» залучилися до процесів злиття й поглинань, «сімка» перетворилася в «четвірку» - Exxon Mobil, Chevron, BP i Shell. У той період нафта продавалася на основі «довідкової ціни», установленої Техаською залізничною комісією приблизно на рівні 2 доларів США, що багато в чому зумовило комфортні умови загального економічного розвитку США й низки європейських країн. Це «благополуччя» закінчилося після «нафтового шоку» 1973 р., 
коли навіть найближчий союзник Вашингтону, король Саудівської Аравії, оголосив мораторій на експорт нафти в США й Голландію за підтримку зброєю Тель-Авіва в черговій арабсько-ізраїльській війні. Відтоді «сонна» ОПЕК отримала друге дихання та порушила механізм «довідкової ціни».

Природно, що в період біполярності Радянський Союз також прагнув об'єднати деяку частину країн, що розвиваються, у групу так званих держав соціалістичної орієнтації. Але формаційний рівень цієї групи загалом не дотягував навіть до ранньокапіталістичного розвитку, а ресурси СРСР були обмежені протиборством із західними країнами.

Звичайно, у період біполярності жодна 3 держав, що розвивалися, навіть із найбільших, не могла самотужки кинути реальний виклик США та союзникам. Більшість із них були зайняті внутрішніми проблемами й конфліктами; суперечності національно-державного будівництва приводили інколи до прямих збройних зіткнень; однак поки наддержави з'ясовували свої стосунки в рамках біполярної структури, у світі повільно, але неухильно накопичувалися елементи або, образно кажучи, «будівельний матеріал» для майбутнього багатополюсного (поліцентричного) світу. Так, із початку 1960-х років лідери ряду «прогресивних» країн (Індії, Югославії, Болгарії, Індонезії, Цейлону) стали поділяти ідею неучасті у військовополітичних блоках, із якої виріс Рух неприєднання, який швидко набрав сили (до початку 1990-х років чисельність його учасників була більшою за сотню). Іншим проявом цієї тенденції став регіоналізм, але без участі західних «покровителів» (АСЕАН, МЕРКОСУР й ін.). Цей рух, у результаті, слугував засобом і сходинкою для поступового залучення країн-учасниць у процес глобалізації.

Із розвалом біполярності почався етап інтенсифікації становлення багатополярного (поліцентричного) світу. Процес цей вирізняється нерівномірністю: $з$ одного боку, за темпами й послідовністю накопичення потенціалу конфліктності між майбутніми полюсами (центрами), 3 іншого - зі створення різних структур розвитку - соціально-економічного, військово-політичного, демографічного - усередині таких полюсів. Так, у низці держав Азії виник феномен «економічного дива». За Японією послідувала Південна Корея, у наступний ешелон увійшли деякі країни Південно-Східної Азії (Сингапур, Малайзія, Таїланд, підтягується Індонезія). Нарешті, Китай «прокинувся» від потрясінь маоїстських експериментів; продумані й послідовні реформи, розпочаті Ден Сяопіном, вивели країну на траєкторію чвертьстолітнього безперервного зростання ВВП. Створення сучасних збройних сил, вражаючі успіхи в зовнішній торгівлі (у тому числі в торгівлі зі США, Японією, Південною Кореєю 
й багатьма іншими країнами), стрімке зростання зарубіжних інвестицій, найбільші інвалютні резерви (уключаючи американські казначейські бонди) - усе це й багато іншого свідчить про те, що Китай твердо стоїть на шляху перетворення в один із найбільших центрів багатополюсного (поліцентричного) світу. Деякі експерти у зв'язку з цим зробили висновок про новий біполярний світовий порядок, що формується США та КНР. Відомо, що ряд високопоставлених американських чиновників поділяє цю думку, і Китаю робилися навіть пропозиції щодо створення «дуумвірату». Але мудре китайське керівництво, маючи перед очима досвід взаємин і з СС, і з Росією, дипломатично відхилило цю пропозицію. Лідер КНР Сi Цзіньпін виступив із «новою концепцією партнерства», у рамках якої Китай позиціонується як «велика країна, що розвивається» [7]. Китайське керівництво засуджує прагнення Вашингтону «скувати» КНР ланцюгом двосторонніх угод із сусідніми країнами під гаслом «США повертаються в АТР» (хоча вони ніколи й не йшли з цього регіону). Адміністрація Б. Обами доклала найактивніших зусилль для підписання в лютому 2016 р. угоди про Транс-Тихоокеанське партнерство, що складається з 12 країн (без участі Росіi). Голова КНР Сі Цзіньпін виступив із пропозицією про формування Азійсько-Тихоокеанської зони вільної торгівлі. Ця ініціатива була реалізована 15 листопада 2020 р., коли 15 країн Азійсько-Тихоокеанського регіону підписали угоду про створення найбільшої у світі регіональної зони вільної торгівлі «Всебічне регіональне економічне партнерство». Угоду в останній день онлайн-саміту Асоціації держав Південно-Східної Азії (АСЕАН) підписали 10 членів цієї Асоціації: В'єтнам, Камбоджа, Таїланд, Індонезія, Сингапур, Бруней, Лаос, Малайзія, М'янма й Філіппіни, а також Китай, Японія, Південна Корея, Австралія та Нова Зеландія. Країни Азійсько-Тихоокеанського регіону, уключаючи Китай, Японію й Південну Корею, підписали найбільшу у світі регіональну угоду про вільну торгівлю, яка охоплює близько третини світового населення та валового внутрішнього продукту [8].

Успіхи Китаю дали підстави деяким експертам говорити про зміну світового лідера (перевищення показників ВВП США). Однак зазначимо, що показник ВВП нічого не говорить нам про його структуру та якість. У Китаю величезна частка ВВП має джерелом індустріальний сектор. Рівень урбанізації країни ще не дуже високий: міське населення становить $51 \%$, існує великий розрив подушного доходу з населенням у сільській місцевості. Окремі елементи IT-сектору, який остаточно не сформувався, представлені або філіями великих міжнародних корпорацій, або гонконзькими й тайванськими фірмами (наприклад виробниками чіпів), або спільними 
підприємствами з іноземним капіталом. Отже, у формаційному відношенні Китай ще довго буде розвиватися за моделлю «наздоганяючої країни».

Керівники КНР не мають ілюзій із цього приводу: вони свідомо не бажають втягуватися в гонку за «наддержавний статус», який вельми обтяжливий для країни i, врешті, малопродуктивний, особливо в сучасних умовах. Тому вони вважають за краще дотримуватися стратегічного партнерства з усіма великими державами.

Що стосується Росії, то після розвалу СРСР вона втратила ціле десятиліття в ході ініційованого Б. Сльциним процесу «розкидання каміння» («беріть стільки суверенітету, скільки зможете проковтнути» [9, с. 9-19], який мало не призвів до розвалу самої Росії, і ще більше у зв'язку з хижацьким і паразитичним розгулом швидко сформованого бюрократичного капіталу. У цей період у Росію ринулись експерти зі США, що давали вказівки навіть на урядовому рівні. Деякі з них, користуючись інсайдерською інформацією, брали участь у прибутковому бізнесі. Результат виявився вельми сумним: економічний потенціал Росії скоротився вдвічі (і це в мирний час), і в умовах наростання корупції країна, яка майстерно спрямовується міжнародними фінансовими організаціями, дійшла до дефолту в 1998 р. Чи не здається нам цей приклад «до болю близьким і знайомим» в умовах сучасної України?

У 2000-ні роки Росія зайнялася «збиранням каміння». Після терактів 11 вересня 2001 р. в США Росія включилася в процес боротьби 3 міжнародним тероризмом. Однак у цей же час, крім об'єднання в боротьбі з тероризмом, почалися процеси, які підтримували США, стосовно просування НАТО до кордонів Росії. Це призвело до відвертої протидії з боку керівництва Росії геополітичному натиску. У відповідь проти Росії був включений процес санкцій, який не підтримали Китай, Індія, Туреччина, Сербія, Сгипет, Бразилія, Венесуела та інші держави. Неоднозначно розглядають «силу» санкцій і різні політичні сили в ЄС. Санкції завдають шкоди як Росії, так і більшості членів ЄС. Росія, спираючись на свою багатовекторну зовнішню політику, намагається стати ще одним важливим центром у межах формування багатополюсного (поліцентричного) світового порядку.

Говорячи про новий світовий порядок, було б невиправдано не згадати ще одну тему. Кілька років тому здавалося, що Свросоюз, безсумнівно, міг би претендувати на роль ще одного великого й впливового центру в рамках майбутньої багатополюсності. ЄС удалося більш-менш зрівнятися за ВВП із головним конкурентом - США. На одному із самітів вирішено подолати відставання від американського IT-сектора. Але з другої поло- 
вини 1990-х років високі показники зростання в більшості членів СС стали сходити нанівець, i, навпаки: показники безробіття почали бити рекорди (особливо серед молодого працездатного населення). Отже, основні цілі Маастрихського договору не були досягнуті. Безумовно, це масштабна й багато в чому суперечлива тема; тут ми обмежимося деякими короткими зауваженнями з питань, яким приділяється, вважаємо, недостатньо уваги.

По-перше, процес інтеграції в ЄС був надмірно форсованим i за темпами, і за розширенням складу. У підсумку, Союз став надто гетерогенною спільнотою національних держав, що і в спокійні роки являє собою важкопереборні перешкоди, а в періоди глобальних криз, на відміну від США, поглиблює кризу структурну.

По-друге, Маастрихський договір передбачав демократичні методи інтеграції і іiі регулювання, а наднаціональна союзна надбудова - брюссельську бюрократію (як і будь-яка бюрократія за «законом Паркінсона»), консолідувавшись, узурпувала основоположні функції національних держав - проведення незалежної економічної політики й можливість незалежного залучення позик і кредитів. Витончена Постанова 1466/97 замінила ці дві суверенні функції обов'язками виконання програм, що пропонуються кожній країні Брюсселем [10]. Брюссельська бюрократія фактично почала будувати «об'єднаний європейський дім» із даху, підриваючи основу функціонування економік членів Союзу, пригнічуючи ініціативу на національному рівні.

По-третє, посилення авторитаризму брюссельської бюрократії було досить вигідне Вашингтону: воно давало змогу використовувати цей невеликий інституційний прошарок для підпорядкування всього СС із метою реалізації власних геополітичних і геоекономічних інтересів, зокрема блокування поглиблення взаємовигідного економічного й енергетичного співробітництва членів СС із Росією, а також запобігання перетворенню $Є С$ в автономний центр впливу в майбутньому багатополюсному (поліцентричному) світі. За останні 15 років Вашингтон досяг неабиякого успіху в трансформації СС у «неспроможного претендента» на статус такого центру впливу, при цьому ще й з урахуванням недавнього виходу вже з Свропейського Союзу такого потужного члена, як Великобританія.

Чи зможе $Є С$ позбутися цієї опіки й хто йому в цьому допоможе? Голова КНР Сі Цзіньпін під час одного з візитів до Свропи, представляючи свою вже згадану вище «нову концепцію партнерства», охарактеризував СС як «найбільше об'єднання розвинених країн» [7]. Чи зможе цей китайський «аванс», виданий $€ C$, посприяти його виходу з-під тіні Великого брата? 


\section{3. ВИСНОВИ ТА ПЕРСПЕКТИВИ ПОДАЛЬШИХ ДОСЛІДЖЕНЬ}

У Сполучених Штатах Америки відбулася зміна влади. Новообраний президент США Джозеф Байден сформував нову адміністрацію Білого Дому. Починається новий етап у міжнародній політиці. Як уже зазначалося в статті, у світі буде продовжено процес розподілу сфер впливу. Цей процес довготривалий та невідворотний. Утворення нового світового порядку й надалі буде актуальною темою дослідників. Автор планує й у подальшому аналізувати трансформаційні процеси у світі та їх вплив на формування нового світового порядку.

\section{СПИСОК ВИКОРИСТАНИХ ДЖЕРЕЛ}

1. Мойсес, Наїм (2018). Від владних кабінетів до полів битви й церков, а потім $i$ до держави, або чому сьогодні бути при владі означає зовсім інше, ніж колись/Мойсес Наїм; пер. $з$ англ. О. Дем'янчук. Київ, 448 с.

2. Walsh, B. (2015). The American Century Isn't Over. Time (2015.12.03). URL: http://time.com/3741856/the-american-century-isnt-over/

3. Clover, C. (2015). Chinese arms sales surge $143 \%$ in 5 years. Financial Times (2015.16.03). URL: http://www.ft.com/intl/cms/s/0/52eb31a4-cb99-11e4-aeb500144feab7de.html\#axzz3Vrc9ALTW

4. Rachman, G. (2015). China's money magnet pulls in US allies. Financial Times (2015. 16. 03). URL: http://www.ft.com/intl/cms/s/0/cd466ddc-cbc7-11e4-aeb500144feab7de.html\#axzz3Vrc9ALTW

5. Интересы РФ и США в отношении Украины несовместимы друг с другом. Коммерсантъ (19.12.1914). URL: http: //www.kommersant.ru/doc/2636177

6. Daniel, Yergin. (1991). The Prize: The Epic Quest for Oil, Money, and Power. США: Simon \& Schuster, 397-398, 403-404.

7. Виноградов, А. О. (2014). Европейское наступление Пекина - тактика или стратегия? Проблемы Дальнего Востока, № 5, 51.

8. 15 країн Азіатсько-Тихоокеанського регіону підписали найбільшу в світі угоду про вільну торгівлю. URL: https://lb.ua/world/2020/11/15/470648_15_krain aziatskotihookeanskogo.html

9. Газета «Известия», вып. 8 августа 1990.

10. Симония, Н. А., Торкунов, А. В. (2014). Энергобезопасность ЕС и Россия. Полис. Политические исследования, № 5, 9-19.

\section{TRANSFORMATION PROCESSES IN THE WORLD AND THEIR INFLUENCE ON THE FORMATION OF A NEW WORLD ORDER}

The article considers the division of the world between developed countries: why there is a need to delimit countries on a certain basis, how the distribu- 
tion is carried out, what structural elements are involved and what happens to the geopolitical situation due to the division of spheres of influence. The author emphasizes the longevity, consistency and inevitability of these processes. The scientific novelty of the article is not only to use the author's philosophy to build a logical model of the world order, but also to use historical, economic and political approaches to a comprehensive analysis of this issue and the deprivation of subjectivity in its assessment. The study considers the concepts of bipolarity, unipolarity and multipolarity - their meaning, essence, practical examples from the history of mankind. The author conducts an ontological analysis of the world order as an important component of human existence. The main attention is paid to the superpowers: the USA and the USSR. The author determines the factors led to the hegemony of these countries and the relevant challenges for today. The main attention is paid to the collapse of the Soviet Union as a natural end of the cycle of superpower domination and the fall of the bipolar picture of the world. As a result, a new world order is emerging, led by many states and international groups, which indicates the transition to a multipolar division of the world by spheres of influence. The author examines the transformational processes that have occurred as a result of this transition, describes the main leaders and contenders for the new hegemon. The main favorite is China - the author carefully examines international activities, socio-economic indicators, politics and Chinese views on the position of the superpower. However, the article highlights a group of factors of supranationalism, which objectively do not correspond to China or its main competitors, the EU and Russia. The main points that hinder the above-mentioned countries and prevent them from taking the place of the new world hegemon are analyzed.

Key words: bipolarity, unipolarity, polycentricity, world order, new world order, superpower.

\section{REFERENCES}

1. Moises, Naim (2018). Vid vladnykh kabinetiv do poliv bytvy y tserkov, a potim i do derzhavy, abo chomu sohodni buty pry vladi oznachaie zovsim inshe, nizh kolys/ Moises Naim; per. z anhl. O. Demianchuk. Kyiv, 448.

2. Walsh, B. (2015). The American Century Isn't Over. Time. (2015.12.03). URL: http://time.com/3741856/the-american-century-isnt-over/

3. Clover, C. (2015). Chinese arms sales surge $143 \%$ in 5 years. Financial Times. (2015.16.03). URL: http://www.ft.com/intl/cms/s/0/52eb31a4-cb99-11e4-aeb5-00144feab7de.html\#axzz3Vrc9ALTW

4. Rachman, G. (2015). China's money magnet pulls in US allies. Financial Times. (2015. 16. 03). URL: http://www.ft.com/intl/cms/s/0/cd466ddc-cbc7-11e4-aeb5-00144feab7de.html\#axzz3Vrc9ALTW 
5. Interesy RF i SShA v otnoshenii Ukrainy nesovmestimy drug s drugom. Kommersant (19.12.1914). URL: http: //www.kommersant.ru/doc/2636177

6. Daniel, Yergin. (1991). The Prize: The Epic Quest for Oil, Money, and Power. США: Simon \& Schuster, 397-398, 403-404.

7. Vinogradov, A. O. (2014). Evropejskoe nastuplenie Pekina - taktika ili strategija? Problemy Dal'nego Vostoka, 5, p. 51

8. 15 krain Aziatsko-Tykhookeanskoho rehionu pidpysaly naibilshu v sviti uhodu pro vilnu torhivliu URL: https://lb.ua/world/2020/11/15/470648_15_krain_aziatskotihookeanskogo.html

9. Gazeta «Izvestija». Vyp. 8 avgusta $1990 \mathrm{~g}$.

10. Simonija, N. A., Torkunov, A. V. (2014). Jenergobezopasnost' ES i Rossija. Polis. Politicheskie issledovanija, 5, p. 9-19.

Матеріал надійшов до редакиії 17.01.2021 p.

УДК: 355.424.4:327.5

Леонід Чупрій,

доктор політологічних наук, професор кафедри філософії, політології та глобальних міжнародних процесів, Університет Державної фіскальної служби України, ORCID ID 0000-0001-7221-5703 chupriy2006@ukr.net

DOI 10.29038/2524-2679-2021-01-45-62

\section{КЛЮЧОВІ КОНЦЕПТУАЛЬНІ ПІДХОДИ ДО ДОСЛІДЖЕННЯ СИСТЕМИ МІЖНАРОДНИХ ВІДНОСИН}

У статті висвітлено ключові концеппуальні підходи до дослідження системи міжнародних відносин. Так, ідеологічним підгрунтям ідеалістичної концепції є загальнолюдські моральні норми, цүінності та ідеали Згідно з концепцією політичного реалізму, у центтрі уваги завжди перебуває держава, яка виступає головним, проте не єдиним актором міжнародних відносин. Анархічність природи міжнародних відносин - один із вихідних імперативів політичного реалізму, щзо відокремлює їх від сфери внутрішніх суспільних відносин. Із погляду транснаціоналістичного підходу, держави вже не є єдиним изентральним актором міжнародних відносин завдяки різноманітності інших суб’єктів: міжнародних організацій, транснаціональних корпоращуій, суспільних рухів тощз. Теоретики неофункціоналізму досліджували ненасильницьькі засоби та механізми

(C) Чупрій Л., 2021 